\title{
Onshore power one option to reduce air emissions in ports
}

\author{
Iven Krämer ${ }^{1,2}$ • Ernest Czermański ${ }^{3,4}$ iD
}

Published online: 25 May 2020

(c) The Author(s) 2020

\begin{abstract}
Ports are not just nodal points in global supply chains but at the same time, they are concentration points for air emissions. Ships that are manoeuvring within estuaries and within the port areas and ships at berth contribute to a large extend to the overall air pollution in port cities. Thus, the efforts to reduce these emissions are not only left to the shipping lines themselves, but to port authorities, port operators and port cities as well. One option that lately has gained huge political interest is onshore power supply. Consequently, more and more ports in the world begin to plan and implement such installations. For the time being, this process is yet in an initial phase and even if different technical solutions do exist and prove their usability in daily operations, the needed investments for the installations do barely see any economic viability. The same is to observe for the operational costs, which is why a discussion for a general obligation to use shore power in ports is ongoing. Time will show if shore power really is a solution or if shipping lines will find even better options to reduce air emissions on their path towards a zero emission shipping.
\end{abstract}

Keywords Green shipping · Green-ports onshore Power Supply · Electrification of ports · Air emissions

\section{Introduction}

For both, shipping and ports air quality is an issue of highest priority. There are new and stricter regulations in combination with self-defined ambitious goals for a zero emission future that drive the shipping lines and the charterers. At the same time, there is an increasing pressure by local communities to tackle the existing problem of air pollution in urban ports. This combination in line with new political priorities of the European Commission like the "green deal" define the way towards new and more activities in shipping and ports. Numerous actions and projects are under way for the uptake of sustainable and alternative transport fuels, the

Iven Krämer

Iven.Kraemer@wah.BREMEN.de

Ernest Czermański

e.czermanski@ug.edu.pl

1 Hochschule Bremen-City University of Applied Sciences, Bremen, Germany

2 Port Economy and Shipping, Ministry for Science and Ports, Bremen, Germany

3 Faculty of Economics, Department of Maritime Transport and Seaborne Trade, University of Gdansk, Gdansk, Poland

4 Armii Krajowej 119/121, Maritime Economy Division, 81-824 Sopot, Poland extension of the Emissions Trading System to the maritime sector, the increase of EU's 2030 emission reduction target to at least $50 \%$ by 2030 , the review of the Energy Taxation Directive and the zero-pollution ambition including air and water quality.

From the port's perspective to date electrification seems to be a key activity. Port authorities go for electrical mobility with cars, buses and bicycles; they test and install battery power on their workboats and tugs; they investigate the future security of their electrical grids and connections and almost everywhere, they create plans and ideas for onshore power supplies (OPS) to all kinds of boats and seagoing vessels. In some 50 global port's OPS-projects and installations have already been made. Terminal operators at the same time are investigating and investing into electrical equipment like electrical cranes, stackers, carriers and so on. They aim for a zero-emission port operation.

Similar to the port stakeholders shipping lines also plan for fewer or no emission-operations. With a view to ports electrification projects like the installation of battery power are of highest importance, because the charging of car, terminal equipment or ship batteries will most likely be an additional task for the ports of the future. The fast-growing energy consumption from port operations as well as from ships leads to the question if the availability of electrical energy can be guaranteed and if the existing electrical net- 
works and substations within the ports are capable to the additional requirements.

As of 2019, 574 seagoing ships with on-board OPS installation are in operation, $81 \%$ of which are full container ships (466). The average length of this group of ships is $300 \mathrm{~m}$, the average load capacity is $82,590 \mathrm{dwt}$ and the average engine room power is $51,030 \mathrm{~kW}$. For the moment, it is therefore not a large group of seagoing ships as far as the entire world fleet is concerned. On the other hand, among the container ships, cold-ironing is already equipped with as much as $8 \%$ of the whole group of ships (https:// maritime.ihs.com).

\section{Air quality-on top of the agenda for shipping and ports}

Besides the overall economical perspective, these days there is just one concern, which dominates shipping conferences, industry discussions and managerial decisions within the shipping sector-air quality.

With the introduction of the global $0.5 \%$ sulphur cap on marine fuels in 2020, the IMO NOx Tier III requirements for vessels built from January 2021 onwards operating in the North and the Baltic Seas (NECAs), the Sulphur Directive and the new National Emission Ceiling Directive the shipping sector faces an intensifying regulatory framework. The targets are clearly defined, first an intense reduction of emissions and in the longer perspective an emission free global shipping sector. IMO has therefore in 2018 set three levels of ambition:

- To decline the carbon intensity of ships through the implementation of further phases of the energy efficiency design index (EEDI) for new ships.

- To decline the carbon intensity of international shipping (reduction of $\mathrm{CO}_{2}$ emissions by at least $40 \%$ by 2030 , compared to 2008).

- To peak and decline GHG emissions from international shipping (reduction of total annual GHG emissions from the sector by at least $50 \%$ by 2050 , compared to 2008 ).

The International Chamber of Shipping (ICS) notes in its annual review from the year 2019, "ICS is acutely aware of the urgent need ... to eventually eliminate GHG emissions as soon as practicable through a combination of short and long term measures ... The transition to zero $\mathrm{CO}_{2}$ emitting fuels ... is the challenge of our age ..."

In addition, the latest Environmental Report from the European Seaports Organisation (ESPO) demonstrates that the issue of air quality is also the top environmental priority for the managing bodies of European ports and this since almost ten years now (Fig. 1). The following aspects of importance are energy and climate change. This result does not come as a surprise as air quality has increasingly been a priority for citizens of port cities and urban areas in general. There are profound studies that prove that air pollution causes about 400,000 premature deaths in the EU and hundreds of billions of euros in health-related external costs. According to ESPO, air quality has therefore become a key determinant of public "acceptance" of port activity in the years to come.

\section{OPS installations as an option to improve air quality in ports}

A report from the International Renewable Energy Agency (IRENA 2019) published in October 2019 describes that there are three main routes for reducing the carbon footprint of the shipping sector:

1. improve the design of the vessels themselves to reduce their specific fuel consumption

2. shift from fossil fuels to other alternative fuels and means of propulsion; and

3. Improvement practices during docking periods by securing cold ironing.

The first two options have a clear target based approach. They both fall under the exclusive responsibility of the shipping lines. As the needed investments to meet these requirements are high and some shipping lines seem to have difficulties to fund the additional investments the world's key ports have decided to support the shipping sector on the way towards an emission free future. Under the umbrella of the World Ports Sustainability Program (WPSP) ports have committed themselves to reduce greenhouse gas emissions (GHG) while continuing their role as transportation and economic centres. One of the projects within WPSP is the Environmental Ship Index (ESI). The Environmental Ship Index (ESI) identifies seagoing ships that perform better in reducing air emissions than required by the current emission standards of the International Maritime Organization. The ESI is used by ports to reward cleaner ships i.e. through reduced harbour dues. It evaluates the amount of nitrogen oxide (NOx) and sulphur oxide (SOx) that is emitted and it includes a reporting scheme on the greenhouse gas emission of the ship (www.environmentalshipindex.org). Looking to the overall environmental impact of shipping a target-based approach seems to be the best option, but as especially urban ports have to deal with local emissions the third option of cold ironing or onshore power supply is also of increasing relevance to the industry. This article will focus on the last mentioned option only.

According to the European Commission, onshore power supplies represent an attractive solution to reduce local pollution generated by vessels at berth and there is obviously 


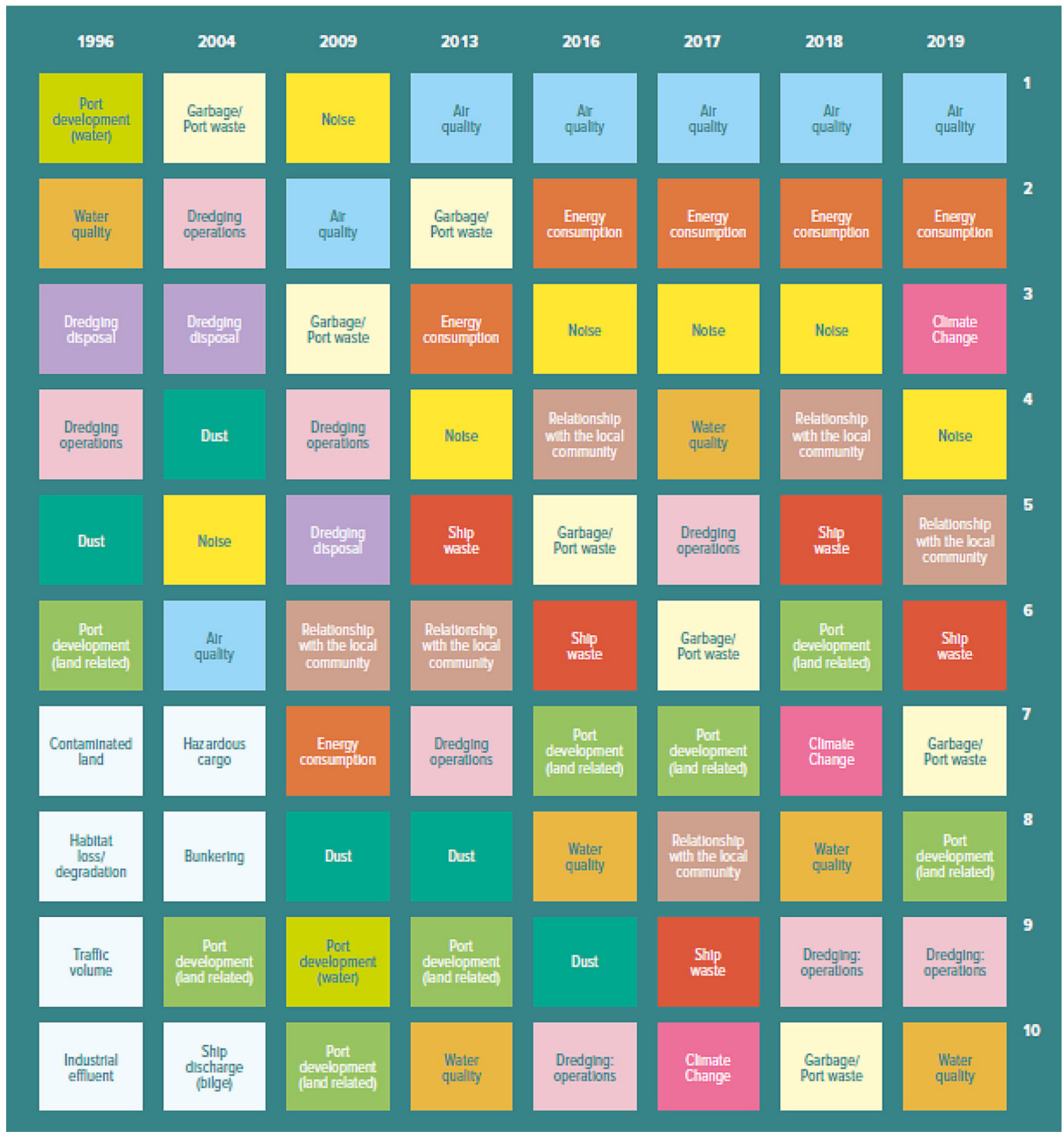

Fig. 1 TOP 10 Environmental Priorities of the port sector over the years. Source: ESPO Environmental Report-EcoPortsinSights (2019, p. 12)

no doubt that OPS installations in ports are an option to minimize emissions within the affected local area. They have an immense positive impact on closed to berth housing areas and the people, which are living and working nearby. Especially in ports with a high frequency of shipcalls and a berth location closed to or even within the citycentre (urban ports) measurements demonstrated emission levels above the allowed limits.
Still these measurements do not automatically shift the responsibility to reduce emissions from the shipping sector towards the ports, but with the direct negative effects, the social pressure on local or regional politicians and the ports self-commitment under the WPSP-scheme there is a growing need to take action from the ports perspective.

As one of the first steps the EU Commission published recommendations for the promotion of shore-side electric- 
ity for use by ships at berth in May 2006 (2006/339/EC). According to these recommendations EU member states should:

1. Consider the installation of shore-side electricity for use by ships at berth in ports; particularly in ports where air quality limit values are exceeded or where public concern is expressed about high levels of noise, nuisance, and especially in berths situated near residential areas.

2. Take note of the advice, set out in the Annex, on the costeffectiveness and practicality of using shore-side electricity to reduce emissions for different types of ships, routes and ports. Nevertheless, the environmental benefits and cost-effectiveness should be evaluated on a case-by-case basis.

3. Work within the International Maritime Organization (IMO), in the context of the ongoing review of the International Convention for the Prevention of Pollution from Ships (MARPOL Convention), to promote the development of harmonised international standards for shoreside electrical connections, taking into account ongoing work.

4. Consider offering economic incentives to operators to use shore-side electricity provided to ships, taking advantage of the possibilities set out in Community legislation.

5. Promote awareness of shore-side electricity among local authorities whose responsibility includes port areas, maritime authorities, port authorities, classification societies and industry associations.

6. Encourage port authorities and industry to exchange best practice concerning shore-side electricity supply and harmonising procedures for this service.

7. Report to the Commission on the action they intend to take to reduce ship emissions in ports, particularly where air quality limit values are exceeded

Already these recommendations underlined that there were immense challenges for OPS installations that need to be solved before many berths will be accordingly equipped. Contrary to the aspects mentioned above with a sole responsibility of shipping lines the implementation of OPS systems is more complex and requires a joint action from the port community together with shipping lines and other partners like energy and network companies.

Two of the main challenges for OPS systems namely the lack of standardization and the not existing economics were directly addressed by Article 4 (5) of Directive 2014/94/UE on Alternative Fuel Infrastructure. According to these member states should:

- Ensure that the need for shore-side electricity supply for inland waterway vessels and seagoing ships in maritime and inland ports is assessed in their national policy frameworks. Such shore-side electricity supply shall be installed as a priority in ports of the TEN-T Core Network, and in other ports, by 31 December 2025, unless there is no demand and the costs are disproportionate to the benefits, including environmental benefits.

- Ensure that shore-side electricity supply installations for maritime transport, deployed or renewed as from 18 November 2017 , comply with the technical specifications set out in point 1.7 of Annex II.

In 2019 an evaluation of Directive 2014/94 has been launched. This will identify how effective these provisions have been to deploy on-shore power supply in European ports. Further to the regulatory approach, the EU Commission has also promoted shore-side electricity as a priority for transport investment within the TEN-T Guidelines. Since 2014 OPS-investments can be supported not just through the Connecting Europe Facility but also through other public support as these investments are eligible under the General Block Exemption Regulation. To further incentivise the deployment and use of cold ironing, Member States can also ask an authorisation to apply a reduced rate of taxation on electricity directly provided to vessels at berth in a port in accordance with Article 19 of the Directive of the Energy Taxation Directive.

\section{OPS system solutions}

The technical options for the provision of seagoing vessels with onshore power supplies can be divided into fixed and mobile installations. There are two general types of fixed OPS-systems. Their main differentiation lies in the question if there is a direct connectivity to the overall public electricity network or of the energy production takes place independently (preferably from renewable sources) with a smart micro-grid shore connection. The main advantage of a fixed OPS-installation connected to the overall network lies in the stability of energy provision. If the energy is produced by renewable energies, this option to date is the most favourable. Technical challenges are the cable connectivity especially at berths with a high tidal range. This often requires the implementation of additional cable troughs and shafts, crane arms, lifting platforms, cable management systems and so on. Furthermore, depending on the capacity of the port network and the needed additional OPS-capacity there might be extra investments into substations and new cables necessary.

Also not all quay walls are easily suitable for these installations because of port operational needs. By this, it is almost impossible to define a certain price for a fixed OPSinstallation. Instead, every system needs to be investigated in depth by the individual needs and requirements. Fig. 2 
Fig. 2 Schematic representation of a fixed OPS-system. Source: Stemmann-Technik, Germany

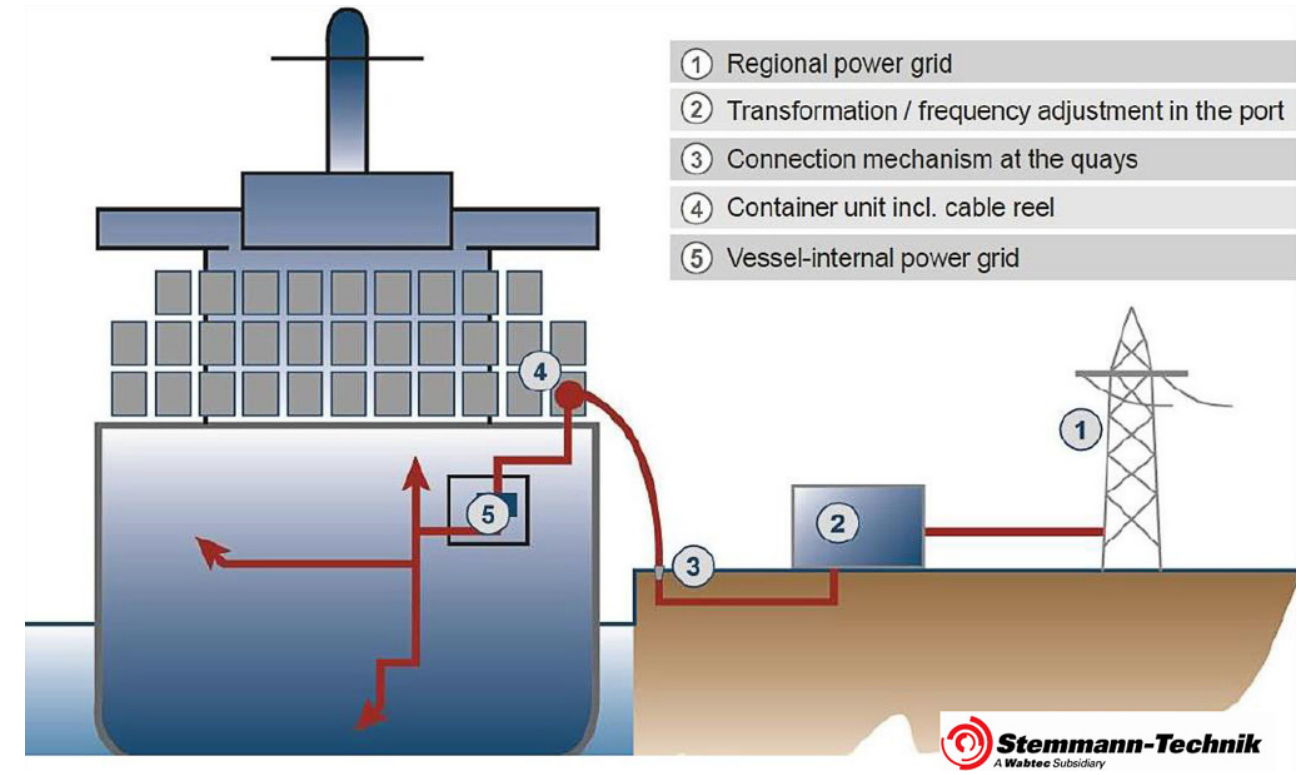

demonstrates the schematic setup of a fixed OPS-system on the example of a container vessel.

There are numerous technology providers for fixed OPSinstallations according to the international norm ISO/IEC/ IEEE-80005-1:2012. Amongst them are Cavotec, Schneider Electric, Cochran Marine, Siemens, Patton \& Cooke, NG ${ }^{2}-$ PLUG-System, SAM Electronics and Stemmann Technik a Wabtec Subsidiary, just to name a few.

Whereas fixed onshore power supply installations are in use already in some ports, there are other options like mobile energy solutions as well available from different technology providers. One option, hat so far has only been a research and test project is a Hamburg based LNG power barge called "Hummel", others are mobile LNG power packs, which have the size of two 40 feet standard containers. Such mobile installations, that are in use in about $16 \%$ of EU ports with OPS might also produce energy with fuel cells or the use of locally produced biofuels. Therefore the Sustainable Development committee of the European Seaports Organization has just recently (October 2019) recommended that there should be no political prescriptions for the technological way to provide onshore power supply, but instead an open approach that supports all technology options. Mobile solutions preferably based on zero emission fuels in combination with smart micro-grids can help to minimize the utilization risk of OPS-systems and can play an important role for the overall electrification of ports.

\section{Status quo for OPS in Europe}

According to the latest ESPO Environmental ReportEcoPortsinSights (2019), based on a survey of 94 Euro- pean ports from 19 different counties, more than half of the ports provide OPS at least on one berth. The vast majority here has installations for low voltage OPS, which mainly relates to inland and domestic vessels as well as auxiliary vessels (e.g. tugs and/or other port authority vessels). Also high voltage OPS systems, which are relevant for seagoing vessels are slowly getting more and more in Europe. The study shows that this number has grown by $10 \%$ from 2016 to 2019 and $29 \%$ of the ports from the sample are planning to provide additional OPS installations within the next two years. A closer look into the European ports then demonstrates that most OPS systems in operation or in planning are directed to the ferry sector or with strong growth figures to the cruise industry. The reason lies in the frequent ferry calls and the unusual long time with up to $40 \%$ that cruise ships spend at berth. Another finding is that these developments have a higher dynamism at some northern European countries (i.e. Sweden and Norway), which brings some shipping representatives to the conclusion that OPS is a more feasible option for richer countries.

Outside of Europe OPS-systems do exist at some berths in North American west-coast ports and in Asia. There as well the tendency to focus first on ferry and cruise berths can well be approved.

\section{Status Quo for OPS in Germany}

Germany or better the German seaports have provided onshore power for more less all berths for port service vessels like tug boats, pilot boats, harbour dredgers, official vehicles from the police, from customs and so on. In addition, most berths for inland barges have shore power installation's. These comparatively easy and inexpensive installa- 
tions evolved over the last years to reach an almost one hundred percent coverage today.

For seagoing ships, until now the situation is completely different. Within the 23 German seaports along the coastline of the North and Baltic Sea and their combined, many hundreds of different berths to date there are only four berths equipped with onshore power supplies. Since 2008, there is the first commercially operated shore to ship connection in Lübeck at the Nordlandkai for the provision of ferry like operated paper and pulp carriers The driver for this pioneering investment was a Swedish shipping line together with the paper company StoraEnso.as the main customer at the berth. In the year 2016 Hamburg installed one OPS at the Cruise Terminal of Hamburg-Altona, which only rarely has been used since. Port of Cuxhaven has due to legal requirements one installation since the year 2018. This is in use by one single ship from the offshore sector. Port of Kiel opened up the latest German OPS investment in summer 2019 to provide ferries that are operating frequently between Kiel and Oslo.

The reasons for these very few installations have been that the investment costs so far are not only very high, but also at the same time uneconomical. Furthermore, there were lots of unclear and unsolved regulatory issues and from the potential users point of view or the shipping lines perspective the operational costs to use shore power have been much higher than just producing the own energy on board. Therefore, the German Federal Ministry of Economy together with the regional ministries in charge for the ports of Germany have signed a Memorandum of Understanding in October 2019. The aim of this joint effort is to reduce the operational costs by easing tax regulations, by guaranteeing reasonable state support for the investment costs and by the intention of a longer perspectives European obligation to use shore power at berth when it is available.

There are plans now for more, so Hamburg wants to install ten additional OPS systems (eight for container vessels and two more for cruise ships) until the year 2022. Port of Kiel will take into operation another OPS system at their cruise berth named Ostseekai. This plant will get an extension cable to provide additionally the Gothenburg-ferry berth, so that the utilization can be improved. Finally, the port of Rostock-Warnemünde will equip two cruise berths in 2020. The very few existing installations together with these plans clearly demonstrate that OPS in Germany like in most parts of the world so far is mainly seen as an option for regular ferry services and publicly perceived cruise ships. However, the other shipping sectors are under investigation as well and plans and concrete decisions might follow soon.

\section{Challenges for OPS installations}

A comparison between the ambitious plans of the EU COM and the description of the current situation in Europe and Germany discloses the gap. Some reasons for the strong restraints have already been mentioned. These are the still missing technical standardization and the overall missing economics for the investments. Other technical challenges are the frequency differences between shore-side electrical grids $(50 \mathrm{~Hz})$ and typical on-board electrical networks $(60 \mathrm{~Hz})$. These differences force the port-partners to invest in frequency and high voltage converters. Electricity shortage at city or regional level may be another barrier. Local grids are often not capable for high voltage OPS systems. This is especially the case in smaller cities. Investments in OPS systems in such locations do therefore require additional multi-million investments into transformation substations and new electrical networks. In view of sustainability, also the question of the source of the electricity is of importance. In general only renewable energy sources should be used to provide shore power to ships.

Furthermore, until today also the operational costs are adversely for OPS. So from the shipping lines perspective the price differential between on-shore and self-produced electricity with marine fuel is another significant barrier for the uptake of OPS. This relates to the Energy Taxation Directive (ETD) that does not provide for an EU-wide preferential tax treatment of shore-side electricity. So far the electricity produced from the combustion of marine fuel on board of ships is tax exempt, whereas ships at berth connects to an OPS system have to pay the energy tax applied to electricity. Such regulation of course can and will be changed to the favour of OPS. To date already some EU member states such as Sweden, Germany, Denmark and Spain have been provided a temporary permit by the EU to apply a reduced rate of taxation to shore-side electricity for ships.

Also levies applied to the electricity price are another barrier. Depending on individual state regulations these may in some cases be even more price relevant as the possible tax exemptions provided by the EU.

Apart from ferry shipping, some cruise companies and some container lines the main part of the global shipping industry is to date quite reluctant to any kind of shore power. This is understandable because OPS as mentioned beforehand is not a solution, which is addressing the overall target of the reduction of shipping emissions. Instead, only the short period in the ports and the local emission reduction effects drive OPS developments. Some shipping lines therefore asses OPS also as being negative for the industries plans towards a full zero emission shipping and regard this as a solution for richer countries only. As long as the 
economics of OPS are not cleared yet these are very comprehensibly arguments.

Therefore and most importantly, investments in OPS systems remain high-risk investments since there is no guarantee or requirements whatsoever for the use of the available installations once provided. As a result all existing OPS installations so far could only be realized by pure public investments or with a high-rate public subsidy. To minimize the financial risk for any potential investor it can be assumed that also in the longer perspective OPS installations will only be economically feasible with an intense public support. For the user perspective, the expectations are more optimistic. Especially in the most relevant sectors of cruise and ferry shipping there is a clear tendency and willingness of shipping lines, to effectively use shore power where available. In fact, this must be organized by the ports as mandatory.

\section{OPS in the emission reduction process}

Switching to OPS means in practice a $100 \%$ reduction in all emissions that would be generated by on-board power generation using MGO or MDO fuel (Walker et al. 2018). There is, however, a very important aspect in this area that is often overlooked in the process of investment in such installations and includes the externalities of the investment. The environmental costs of generating the electricity supplied to the ship by onshore infrastructure must also be taken into account, as this is where the emission shifting effect occurs from the berth of the ship (self-producing electricity) to the location of the power plant supplying the local distribution network of the port. Only if the local grid origin structure is based on renewable energy sources can there actually be a reduction in emissions corresponding to the share of renewable energy sources in total electricity production (Czermański 2019).

The main direct benefits of shore-side power to ships can be considered as the main direct benefits:

- reduction of ship exhaust emissions in the port, thereby improving the air quality of the port and city;

- fuel cost savings for on-board units-provided that shore-side power is purchased at prices lower than the cost of generating it on board;

- reduction of vibrations on board during berths;

- increase in electricity sales to port customers;

- an innovative impulse for the power industry in the design and construction of external power supply networks for ships;

- stimulus to increase the share of renewable energy in the regional/country energy production structure.
OPS technology is effective in correlating the source of power in the port network with the ship's fuel, which it eliminates by switching off the generators at the quay. Given the direct effect of emission reduction, the potential of this solution is very high.

The use of the ship's alternative energy also makes it possible to reduce $\mathrm{CO}$ emissions by $99 \%$ and to reduce $\mathrm{CO}_{2}$ and $\mathrm{NO}_{\mathrm{x}}$ emissions by over $50 \%$. It is estimated that for a typical container ship during a 24-hour berth in a port, the use of cold-ironing technology eliminates emissions of $450 \mathrm{~kg} \mathrm{NO}, 32 \mathrm{~kg} \mathrm{SO}_{\mathrm{x}}$ and $7 \mathrm{~kg}$ of other pollutants. Taking into account the scale of annual transport, the number of vessels and the huge amount of cargo that is transported by sea and then transhipped in seaports, it is not difficult to imagine how significantly the emission of harmful substances into the atmosphere would be reduced (Czermański 2019). Current status is, although, far away from this goal.

The implementation of OPS technology in seaports should also consider how to generate electricity to supply the ship. As in the case of the port of Gothenburg, it should be generated from renewable sources such as wind turbines. However, the use of energy from non-renewable sources in this technology does not exclude the benefits of using it. Studies have shown that regardless of the method of electricity generation, OPS contributes to a significant environmental improvement, as shown by the number of ports where the technology is used and the number of ports that have declared their willingness to introduce an onshore electricity supply system. The implementation of this innovation appears to be an appropriate solution in places where port activities represent a significant burden on the environment and where the environmental benefits, including the improvement of the living conditions of the population, outweigh the financial outlay for such investments (Papoutsoglou 2012).

\section{Conclussions and latest developments}

As shown above there are within the global port community more and more projects for the provision of onshore power supply for seagoing vessels in planning, under development or have just recently been realized. One of those projects focussing on industrial shipping is a joint consortium consisting of Heerema Marine Contractors, Eneco and the Port of Rotterdam Authority. After signing a Memorandum of Understanding to conduct a feasibility study in summer 2019, in October the final investment decision was made. To provide the crane vessels of Heerema, which typically moored at Calland-Canal for a reasonable amount of time and so far using their own engines and as well for ships at other berths nearby, a new "e-house" of 16 by 9 meters including 
several transformers will be built. The important facts of this project are:

- that the power for the seagoing vessels will be directly supplied by wind turbines,

- that the provision of power will be done by a consortium led by an energy company with the port as just a minor partner and,

- that the public authority (here the Municipality of Rotterdam) will support the investment by granting a subsidy of $€ 2$ million.

This distribution of tasks and the sharing of risks reflects the above-mentioned reserves in a most favourable way and clearly addresses the prevailing inefficiency of shore power from the pure ports perspective.

Another positive example is an onshore power supply project in the port of Bergen/Norway. There a quite similar setup has been chosen to simultaneously provide three large additional shore power connections for cruise ships. The main facts here are:

- The needed power will be provided from renewable energies like hydropower,

- BKK, the largest renewable energy company in Western Norway establishes a new company for the installation, operation and maintenance of all shore power connections within the port with the port of Bergen as a minor partner

- Enova, a state owned grant scheme, will support the project financially.

This project setup proves again that onshore power supply cannot only be a task for the ports but instead needs an approach and a support from the wider society.

Funding This report and its related research received no external funding.

Funding Open Access funding provided by Projekt DEAL.
Conflict of interest I. Krämer and E. Czermański declare that they have no competing interests.

Open Access This article is licensed under a Creative Commons Attribution 4.0 International License, which permits use, sharing, adaptation, distribution and reproduction in any medium or format, as long as you give appropriate credit to the original author(s) and the source, provide a link to the Creative Commons licence, and indicate if changes were made. The images or other third party material in this article are included in the article's Creative Commons licence, unless indicated otherwise in a credit line to the material. If material is not included in the article's Creative Commons licence and your intended use is not permitted by statutory regulation or exceeds the permitted use, you will need to obtain permission directly from the copyright holder. To view a copy of this licence, visit http://creativecommons.org/licenses/by/4. $0 \%$

\section{References}

bremenports (2019) Aktuelle Machbarkeitsstudie einer Landstromversorgung für Seeschiffe in Bremerhaven. Ministry for Science and Ports of the Free Hanseatic City of Bremen, Bremen

Czermański E (2019) Morska żegluga kontenerowa a zrównoważony rozwój transportu. University of Gdańsk Press, Gdańsk

Directive 2014/94/EU of the European Parliament and of the Council of 22 October 2014on the deployment of alternative fuels infrastructure

EcoPortsinSights (2019) ESPO environmental report

EU Commission (2006) Recommendation on the promotion of shoreside electricity for use by ships at berth in community ports of 8 May 2006, (2006/339/EC)

IRENA (2019) Navigating to a renewable future: solutions for decarbonising shipping, preliminary findings. International Renewable Energy Agency, Abu Dhabi

Papoutsoglou T (2012) A cold ironing study on modern ports, implementation and benefits thriving for worldwide ports. School of Naval Architecture \& Marine Engineering, University of Athens, Athens, $\mathrm{p} 51$

Walker TR et al (2018) Environmental effects of marine transportation. In World Seas: An Environmental Evaluation, 2nd ed, Vol. 3: Ecological Issues and Environmental Impacts, p 505-530. ISBN 978-0-12-805052-1. Elsevier Ltd. https://doi.org/10.1016/C2015$0-04336-2$ 